\title{
食鳥肉のサルモネラ污染調査とその防止対策
}

VIII. S. sofia 培養菌による㮲経口投与試験

渡辺昭宣* 徳丸雅一* 栗栖 誠* 正木宏幸* 池内俱子* 野田敬子*

(昭和 50 年 10 月 7 日受付)

\section{Surveys and Control of Salmonella Contamination of Chicken Meat}

VIII. Experiments on Oral Inoculation of Chicks with Salmonella sofia Culture

Akinobu Watanabe, M. Tokumaru, M. Kurisu, T. Ikeuchi, H. Masaki and K. Noda

(Division of Food Sanitation, Hygienic Laboratoty, Prefecture of Saitama, Urawa)

SUMMARY

Groups A, B, C, and D of chicks were inoculated orally wiht $1,10^{2}, 10^{4}$, and $10^{7}$ cells per capita of Salmonella sofia culture, respectively. During a period of observation, the organism was not detected from group A, but began to be detected from the digestive tract, feathers, and the bursa of Fabricius in groups B, C, and D on the 21st, second, and first
さきに，著者らは食魚肉のサルモネラ污染の実態およ びこれに対する処理場での実施可能な防止対策について 検討し，污染排除および污染抎大防止にかなり有効な手 段を見出することができた ${ }^{13)}$. しかし，これらの処理場 に护けサルモネラ污染防止対策だけでは食鳥肉の污染 を完全に排除することはできず，食鵎の生産から消費に わたった系統的な対策をたてなければ，これを根絶する ことはできないと考えられる。

最近, 食鳥肉における污染サルモネラのうち, S. sofia は短期間に急激に検出率を高め, ほぼ全国各地で生産さ れたものから検出されるよらになった。 また, 本菌は,生 鶏では内藏よりも羽毛, 表皮から検出されることが多く, と体の体表皮污染が食鳥肉の直接, 間接の污染源となる ことが証明された. いっぽう, 本菌の人における保菌率 も増加の傾向がみられ, また, 食中毒も発生しているの で, サルモネラ症の疫学上注目すべき菌型とみなされ る.

そこで, 食舀に打ける S. sofia の污染経路と, それに 対する病原性を追求するための基礎的研究として, 初生 雛に本菌を経口投与し, 経時的に排菌, 体内分布, 体表 污染および抗体産生の推移を検討した,

\section{実験材料と方法}

\section{1) 供試菌株}

* 埼玉県衛生研究所食品衛生部（浦和市上大久保6391)

日獣会誌 $19 \quad 137 \sim 142 \quad(1976)$ day of observation. Group A and a control group were negative for antibody in the blood. Antibody began to be produced in groups B, C, and D on the 21 st, 14th, and 10th day of observation and increased gradually. The chicks of these three groups seemed to be carriers to induce contamination of the environment and meat.
著者らが食鳥肉のサルモネラ污染調査時に保菌鷄から 分離した S. sofia (strain No. 1920) を用いた.

\section{2）実験雛と飼育方法}

白色レグホン，2 日齢雛 167 羽を県立養鵎試験場より 購入し実験に供した。雛は 1 群 30〜40 羽とし，5群に 分け, バタリー式育雛器 (JPJ ミゼット型 5 段式) で飼育 した. 各階間の污染を防ぐため育㱀器の床と側面下部周 囲を硫酸紙で覆い，最上段に対照群 24 羽を入れ，2段 目にA群 33 羽, 3 段目にB 群 42 羽, 4 段目にC 群35 羽，5段目にD群 33 羽を収容し，上段から下段にゆく に従って投与菌量を増加した.

飼料はブタイラー用 (Vゴールド前期用と後期用. 明 治飼糧）を購入し, 開封時にサルモネラ陰性を確認して 使用した。

\section{3） S. sofia 培養菌の投与方法}

S. sofia のトリプトソイブイヨン $37^{\circ} \mathrm{C} 24$ 時間培養液 を減菌生理食塩水で適当な菌量になるように希釈し， $\mathrm{A}$ 群からC群まではその $0.2 \mathrm{ml}$ を，D群はその $0.5 \mathrm{ml}$ をカテーテルで経口投与した，投与菌量はA群；1～2 個 $/ 0.2 \mathrm{~m} l, B$ 群; $100 \sim 400$ 個 $/ 0.2 \mathrm{ml}$, C 群; $1.1 \times 10^{4}$ 個 $/ 0.2 \mathrm{ml}$, D群； $1.0 \times 10^{7}$ 個 $/ 0.5 \mathrm{ml}$ とした. また, 対照群には減菌生理食塩水の $0.2 \mathrm{ml}$ を同様に経口投与 した.

\section{4） S. sofia 投与後の調査}

（1）雛の投与菌検索

各群とも, 投与後 1 週間は毎日，それ以後は $3 \sim 7$ 日 
間隔で毎回 $2 \sim 3$ 羽を無作為に選出し, 放血と殺後, 羽 毛と蔵器について菌検索を行なった. なお B，C, 群およ び対照群は 7 週間， $\mathrm{A} ， \mathrm{D}$ 群は 4 週間検索を行なった。

検体採取順序は，まず羽毛を体表の各所から採取した 後，頸部を酒精綿でよく清拭し，皮膚を切開したのち同 部位血管を一括切断して放血し，培養用と抗体測定用に わけて採取した。つぎに頸部を持って吊下げ，と体を 3 \%クレデール水に浸し，消毒した後，肝，心，脾，腎 (各 $1 / 2 \sim 1 / 5$ 量), ファブリシウス囊( $1 / 4$ 量), 遺残卵 黄(全部), 嗉囊, 腺胃, 筋胃(内容物の一部), 十二指腸, 回腸, 盲腸, 直腸（内容物を含め $2 \sim 3 \mathrm{~cm}$ ）の順に採取 した。

培養方法は, 試料を $\mathrm{YCC}$ 液体培地（試料の 10 倍量） で $35^{\circ} \mathrm{C} 20$ 時間前培養した後, その $0.5 \mathrm{ml}$ をラパポ 一培地 $10 \mathrm{~m} l$ に移殖して $35^{\circ} \mathrm{C} 20$ 時間選択増菌し, 菌分離は MLCB 平板培地で $35^{\circ} \mathrm{C} 20$ 時間培養で行なっ た. 分離菌の同定は，1平板当たり5１0 個の疑わしい 集落をとり，生物および生化学的性状ならびに抗 S. sofia 血清による疑集反応によって行なった.

(2) ケージ内大便の菌検索

ケージの底に敷いた硫酸紙をとりかえる際, 紙上の大 便を数籄所から $3 \sim 5 \mathrm{~g}$ 集め, 各群とも投与後第 1 週は 毎日，それ以後は $3 \sim 7$ 日間隔で，B，C群および対照 群は 7 週間， A， D群は 4 週間にわたり前記と同様の方 法で投与菌の検索を行なった。なお，床敷の硫酸紙は， 菌検索実施の如何にかかわらず，毎日交換した。

(3) 血中抗体価 $(H)$ の測定

放血時に採取した血清について, 常法に従って定量凝 集反応を行ない，H抗体価を測定した.

抗原には S. sofia ( No. 1290) のトリプトソイブイヨ ソ $35^{\circ} \mathrm{C} 18$ 時間培養菌をホルマリン処理したものを用 い, $50^{\circ} \mathrm{C}$ 水沿中で 2 時間反応させた後, ただちに凝集の 有無を判定した。なお，抗体検查はは投与後 1 週より 7 日間隔で行なった。

(4) 体重測定

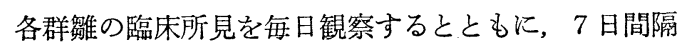
で体重測定を行なった．体重は菌検索用雛の $2 \sim 3$ 羽に ついて放血前に計量し, 各群毎の平均値を算出した.

\section{実 験 成 績}

各実験群とも, 全実験期間を通じて元気, 食欲および 大便の性状についてとくに異常を示さず，また，死亡し たものはなかった．菌投与群と対照群に拈ける体重增加 曲線は図 1 に示すごとくであり, 投与群と対照群の体重 增加率にほとんど差異は認められなかった。

なお， A群 3 羽，B群 2 羽，D群 1 羽の計 6 羽から投 与菌以外のサルモネラが検出された. 菌型はいずれも $S$. senftenberg で, 検出部位は, 遣残畉黄, 腺胃, 羽毛が各

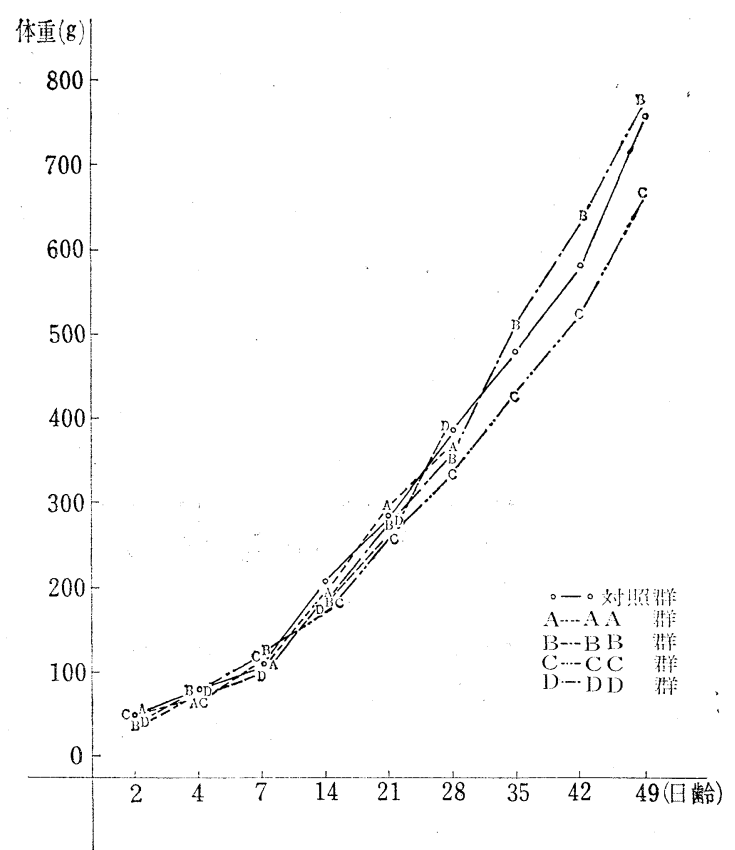

困 1 S. sofia 投与群の体重増加

1 例, 喿整が 2 例, 筋胃, 十二指腸, 回腸が各 3 例, フ

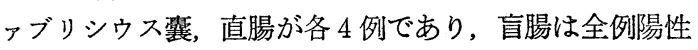
であった。 また，これらの雛からは投与菌 (S. sofia) は 検出されなかった.

\section{1）S. sofia の検出状況}

A群（1 個/羽) は 28 日間, 対照群は 49 日間覲察を 行なったが, その間, 羽毛, 諸臓器および排泄された大 便のいずれからも投与菌は検出されなかった.

$\mathrm{B}$ 群 $\left(10^{2}\right.$ 個/羽) の成績は表 1 亿示すごとくである. 個体別にみると, 第 3 週以後では, すべてのものが, それ ぞれ検査したいずれかの部位に投与菌を保有していた. また, プールした大便では, 投与 10 日以後から陽性と なった。

藏器別にみると投与後 2 週までは, ほとんどの部位が 陰性で, 第 1 日殺 1 例の嗉囊, 回腸, 第 5 日殺の 1 例の 盲腸, 直腸および第 7 日殺の 1 例の嗉囊, 腺胃, 盲腸が 陽性を示したのみであった. 第 3 週以降の投与菌検出状 況をみると, 消化管下部では第 5 週例を除き第 3 週以降 から投与菌が回収されることが多く, 盲腸, 直腸ではほ ぼ全例陽性を示した．また, ファブリシウス辐からは第 4 週以降に投与菌が回収されることが多く, 羽毛は全例 が第 3 週以降に陽性を示した.

1て心，肝，脾は全期間を通じてすべて陰性であり，腎は 第 4 週括よび第 7 週の各 1 例, 連残卵黄は第 7 週の 1 例 がそれぞれ陽性を示した。

C群 (104個/羽) の成績は表 2 亿示す通りである. 個 体別にみると, 投与 2 日以後, 観察終了時までほぼ全例 
渡辺昭宣 德丸雅一 栗栖 誠 正木宏幸 池内俱子 野田敬子

表 1 S. sofia の 臓器別検出状況

$\mathrm{B}$ 群； $10^{2} / 0.2 \mathrm{ml}$ 経口投与

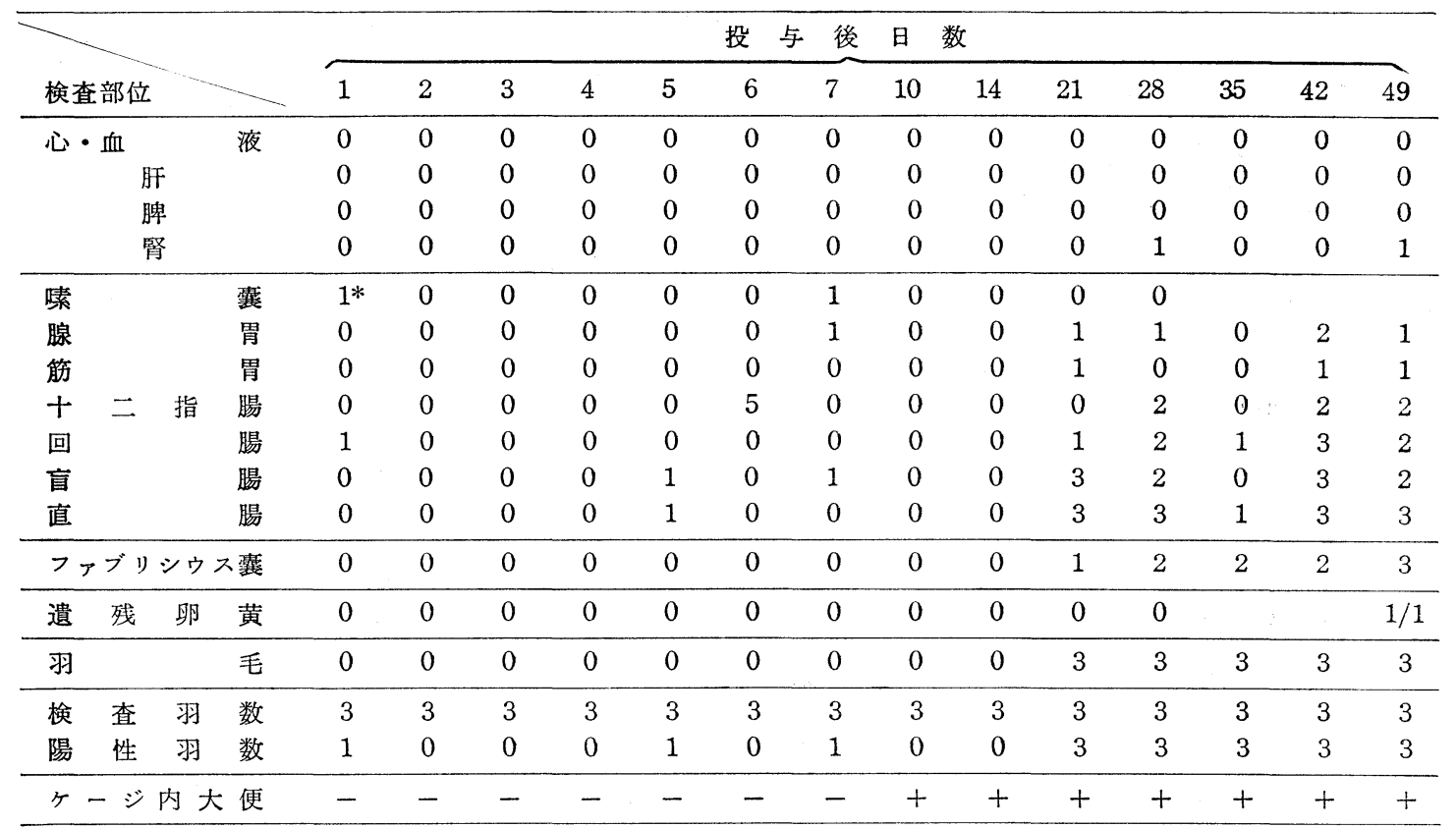

* 陽性例数

表 2 S.sofia の 藏器 別検出状 況

$C$ 群； $10^{4} / 0.2 \mathrm{ml}$ 経口投与

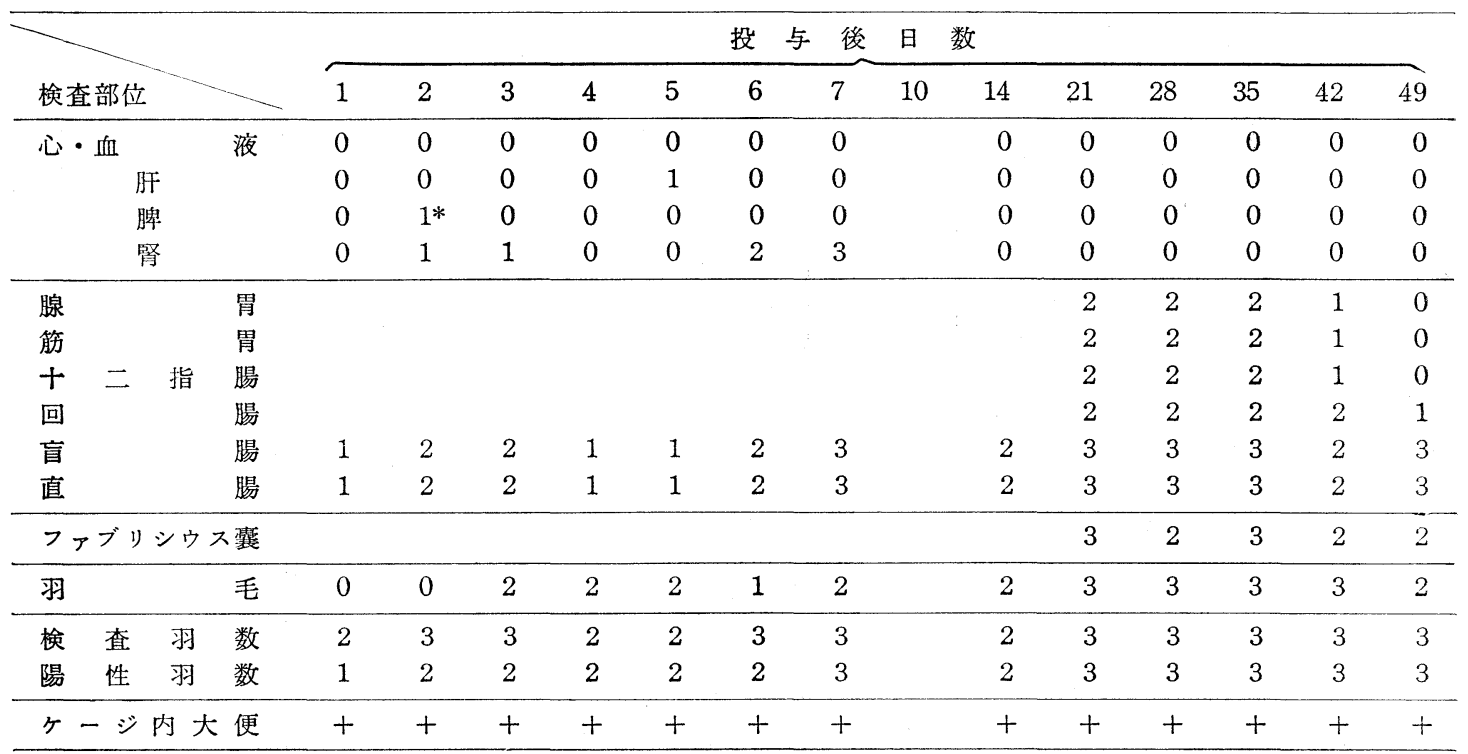

*陽性例数嗉翼および遺残卵黄は検査せず

陽性の成績を示した．またプールした大便は，全期間＼cjkstart除きほとんどのものが全期間を通じて陽性であった.

陽性であった.

臓器別に2ると, 盲腸, 直腸は第 1 日, 第 4 日および 腺胃, 筋胃, 十二指腸および回腸は第 $1 \sim 2$ 週までは検 査を行なわなかったが, 前 3 者は第 $3 \sim 5$ 週, 後者は第 第 5 日例, 羽毛は第 $1 \sim 2$ 日拉よび第 6 日例をそれぞれ $3 〜 6$ 週まで, ほぼ全例陽性であった。また，ファブリ 
食鳥肉のサルモネラ污染調查とその防止対策

表 3 S. sofia の 臟器別検出状況

$\mathrm{D}$ 群；107/0.5 ml 経口投与

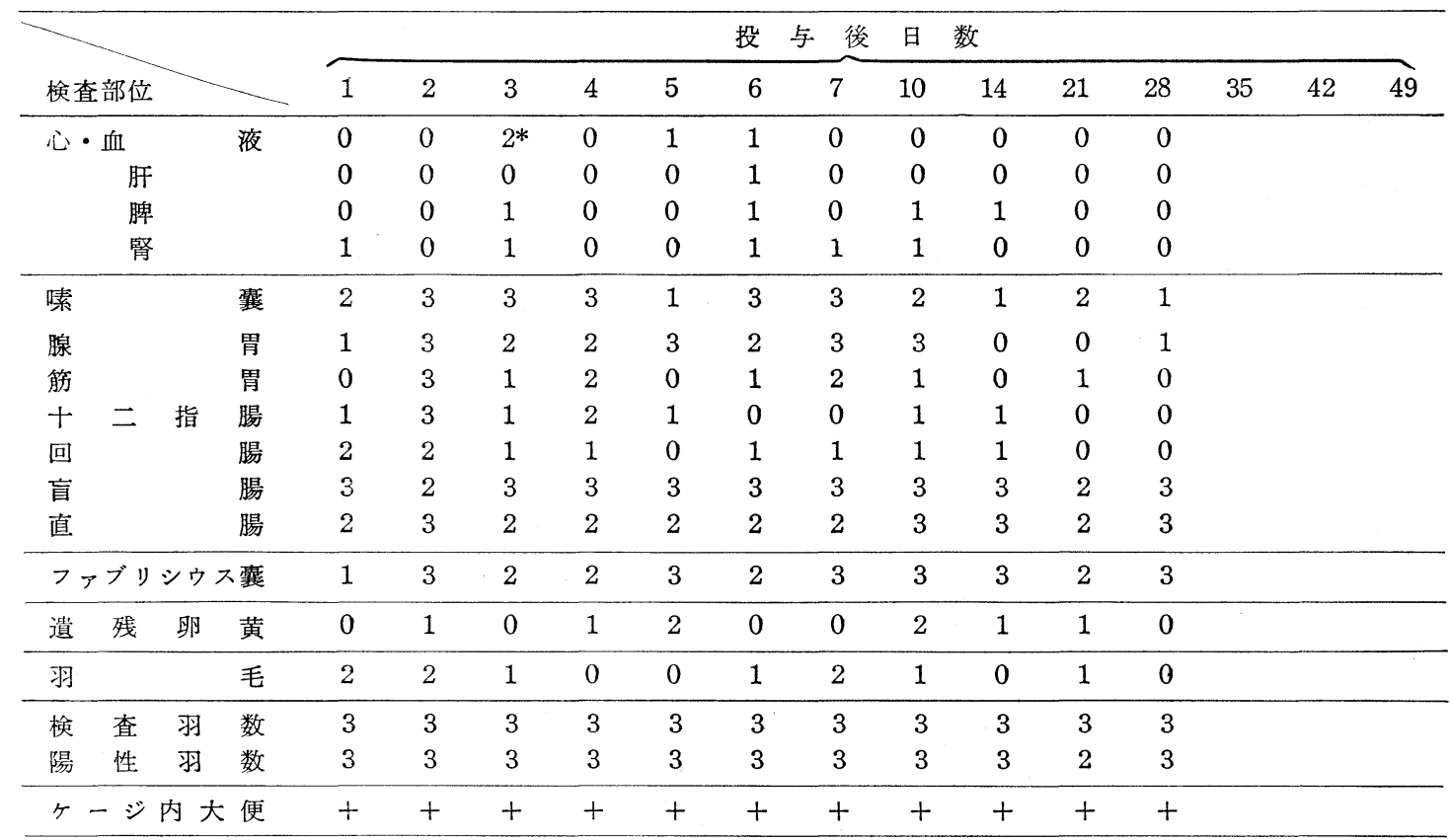

* 陽性例数

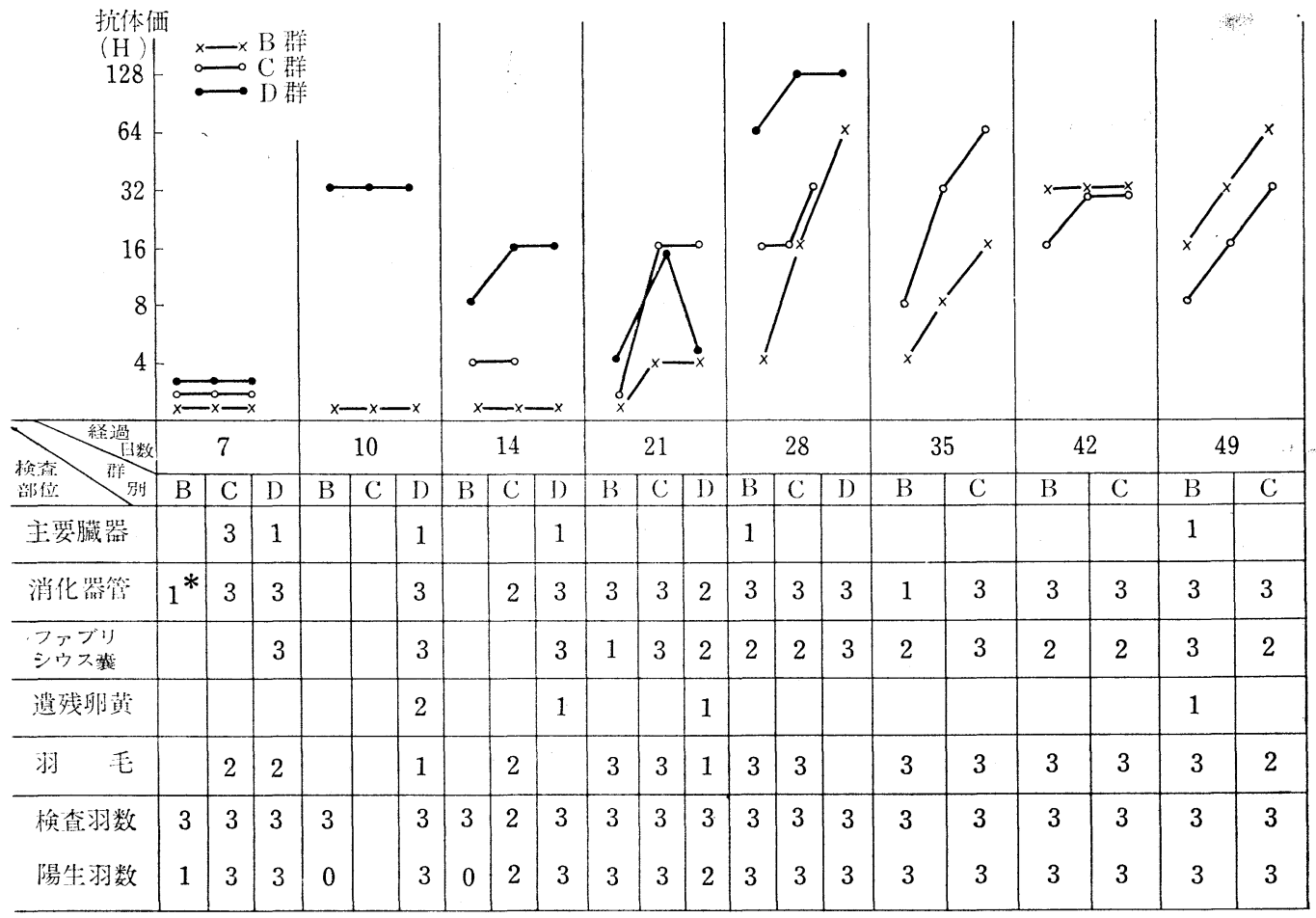

*陽性例数

図2S. sefia 投与菌量と血中 $\mathrm{H}$ 抗体産生状況 


\section{渡辺昭宣 德丸雅一 栗栖 誠 正木宏幸 池内俱子 野田敬子}

シウス囊は第 $3 〜 7$ 週の間のみ検査を行なったが，その 間，ほとんどのものが陽性を示した。

腎は第 2 日，第 3 日に各 1 例，および第 6 日，第 7 日 のほぼ全例が陽性を示した。，心は全期間すべて陰性であ ったが，肝は第 5 日の 1 例, 脾は第 2 日の 1 例のみが陽 性を示した。

$\mathrm{D}$ 群 (107 個/羽) の 成績は表 3 に示すごとくである. 個体別にみると，投与第 1 日後より投与菌はいずれかの 検体から回収された。 また，プールした大便も全期間陽 性であった，臟器別にみると，盲腸，直腸は第 1 日後よ り, ファブリシウス囊は第 2 日後より, 全期間にわた り，注ぼ全例陽性を示した，嗉囊，腺胃は投与 10 日後 までほとんどのものが陽性を示したが，それ以後は検出 頉度は下がる傾向を示した. 腺胃, 十二指腸, 回腸, 遣 残畉黄, 羽毛は全期間, 心, 脾, 腎は投与後 $1 \sim 2$ 週ま で散発的に陽性を示した。

\section{2）血中抗体（H）の出現状況}

各投与群の血中に出現するH抗体の測定は，菌投与 1 週間後より 7 日毎に, 殺処分時に雊から採取した血清に ついて行なった. A群と対照群のH抗体価は, いずれも 陰性 (4 倍以下)であったが, 他の群については図 2 のご とくである. B群では第 14 日まで抗体は陰性であると 同時に，第7 日の 1例を除いていずれからも投与菌は回 収されなかった，第 21 日では 3 羽のうち 2 羽が 4 倍陽 性を示し，その後は個体差はみられるが 4 倍から最高 64 倍までの抗体価を示した. 投与菌も第 21 日以降全例が 陽性を示した. C群では第7 日には抗体の出現はみられ なかったが，第 14 日の 2 羽が 4 倍陽性を示し，第 21 日には 3 羽のらち 2 羽が 16 倍陽性となり, それ以後 8 倍から最高 64 倍の抗体価を示した. 投与菌は第 7 日か ら全例が陽性を示した。 D群では, 第7 日は抗体陰性で あったが，第 10 日後では 4 倍から最高 128 倍までの抗 体価を示した．投与菌は第 21 日の 1 例を除いて，全例 が第7 日から陽性を示した.

\section{考察}

食鳥肉のサルモネラ污染は年々増大しているが，その 分離菌型の推移をみると昭和 44 年には12菌型が検出さ れ, S. thompson, S. typhimurium, S. infantis などの検出頻 度が高かった.ところが, 昭和 47 年になると 6 菌型にな り S. sofia の検出率が最も多く,ついで S. typhimurium, $S$. thompson の順となり, 現在では $S$. sofia が食鳥肉の主要污 染型になった ${ }^{14}$, このS. sofia については貴田ら ${ }^{4)}$ が報 告して以来, 多くの報告 ${ }^{9,12)}$ が双られ, 全国的に食䳕間 に污染が昖がっていることが示されている. また，余田 $ら^{16)}$ は 6 週齢の発病鵎から高率に本菌を分離し, 雛に対 し病原性が強いことを示唆している.

人の感染例については, LUDKIN $\left.(1955)^{5}\right)$, THOMAs
$(1957)^{11)}$ 記載がみられるほか，馬場ら ${ }^{1)}$ は昭和 48 年 の調查から, 生肉に接する女子で下痢, 腹痛を訴える有 症者から約 $40 \%$ に S sofia を検出し, 本菌を含む亜属 IIの人に対する病原性を検討することが必要であること を指摘している.

そこで，著者らはS. sofia の食鷄間に打ける急速な污 染拡大の原因, 本菌の雛に対する病原性を追求するた め，2 日齢の雊を用いて経口投与による感染実験を試み た.

1 個/羽投与例はすべて陰性の成績を示したが, $10^{2}$ 個 /羽投与例では第 3 週以後, $10^{4}$ および $10^{7}$ 個/羽 投与例 では翌日より, 諸㵴器および羽毛から投与菌が検出され た.これらの陽性雛について定量培養試験は行なわれな かったが, $10^{2}$ 群では第 3 週以後, $10^{4}$ 群では第 2 週以後, $10^{7}$ 群では 10 日以後から. それぞれ抗体を産生し, か つ, 体内各所に分布していることよりみて, 雛は本菌に 感染したものとみなされる.

また，いずれの㮲倠も症状を示さず，死亡したものもな いので，いわゆる健康保菌が成立したものと考えられ る.

保菌雊の体内分布の推移をみると, 投与菌量と体内に おける広がりとの間に関係がみられ, $10^{2}$ 群では第 3 週, $10^{4}$ 群では第 4 日， $10^{7}$ 群では第 1 日後に，検出したい ずれかの部位から投与菌が検出された. 保菌部位として は，大腸とくに盲腸，ファブリシウス囊，羽毛などが注 目された。ただし，消化管以外の内臓からの検出率は， $10^{2}$ 群拉よび $10^{4}$ 群では, $10^{7}$ 群に比して低く, また, 羽毛からの検出率は $10^{2}$ 群および $10^{4}$ 群が高く, $10^{7}$ 群 は低かった。

著者ら ${ }^{15)}$ が行なった処理場に投入された食鶏（ $6 〜 7$ 力月踚)の成績と比較してみると, 保菌部位に若干の差が みられる.すなおち, 調査した 137 羽のらち 10 例(7.3 \%) にS. sofia 保菌鵎が見出され，その全例の体表（羽 毛, 皮膚）は陽性であった。これに対し, 内藏より本菌 が検出された例は少なく, 盲・直腸混合内容 4 例, 脾 1 例がそれぞれ陽性を示したのみで，その他の臓器はすべ て陰性であった. 今回の実験感染㮲倠における S. sofia の 分布と, 食舀における差異は, 感染後の日柃によるもの か, それとも感染した菌量にもとづくものか, さらに検 討を要する間題であろう.

今回行なった実験條件下では，保菌の成立に $10^{2}$ 個以 上の菌量が必要であった. 前述のごとく, 2 日龄の雛 を用いたにもかかわらず発症, 死亡した雛は 1 例もみら れなかった.これに対し. 余田ら ${ }^{16)}$ は， 6 週例の発症雊 からS. sofia を高率に検出し, 本菌の雊に対する病原性 を示唆する報告を発表している．田中ら ${ }^{10)} の$ 行なった S. typhimuriumによる感染実験の成績をみると，自然材料 （保菌犬大便）中の菌は，分離培養されたものに比し格 
段に病原性が強く，少量菌（数十個）の経口投与で犬は 無症状感染（保菌）し，また，マウスは敗血症死するこ

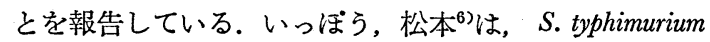
の大量の培養菌を子犬に経口投与した場合, ッリガネチ マダニの濃厚感染をうけ, 一般状態の悪い個体は敗血症 死したことを記載している, したがって, 本菌対鶏の関 係に怙いても, さらに菌側および宿主側の条件を考慮し た検討が必要であろう.

鷄に拈ける保菌を含むサルモネラ症の疫源として，污 染飼料が注目されている.しかしながら, 污染飼料中のサ ルモネラ菌量は一般に少なく, 通常, 飼料 $1 \mathrm{~g}$ あたり 1 個 以下といわれる。 また， S. sofia を飼料から検出した報 告は内外を問わず見当たらない、2,3、7,8). したがって, 鶏に S. sofia が到達するルートは，いまだ未解決といえる。 た, 前述のごとく, 䳕が S. sofia を保菌する, あるいは感 染発症する機序，保菌の持続期間などについては検討を 要する問題が残されているが，ひとたび保菌が成立すれ ば長期間にわたって保菌鷄は排菌するので，鷄舎の諸環 境を介して污染は拡大し, ひいては食鳥肉の污染に結び つくものと思われる.この事は, 塚本ら として S. sofia に污染された養鷄場についての調査で, 直腸内大便よりの本菌の検出率は低いが，鷄舎内に排泄 された大便からは高率に分離され，かつ，該養舀場由来 の食鳥肉に少なからず S. sofia の污染があることでも裏 付けられている. したがって, これらの事実は, 食鳥肉 のサルモネラ污染防除には, 孵卵, 育雛段階から一貫し た適切な処理が必要であることを示しているものと考兄 られる。

\section{結論}

1. S. sofia 培養菌の 1 個/羽, $10^{2}$ 個/羽, $10^{4}$ 個/羽拧 よび $10^{7}$ 個/羽の各菌量を白色レグホン 2 日齢雛に経口 的に投与し， $4 \sim 7$ 週間観察を行なったが. 各投与群と も 1 羽の死亡例もなく, 臨床的に異常は認められなか った. また, 体重増加率も投与群と対照群とに殆んど差 異がみられなかった。

2. S. sofia 培養菌 1 個/羽投与群 (A 群) と対照群か らは観察期間中羽毛, 諸臟器およびヶージ内大便からの 投与菌の検出はなかった。

$10^{2}$ 個/羽投与群 (B群) では第 21 日以後において,

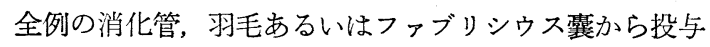
菌が検出された。 また，ケージ内大便は投与第 10 日後 から全期間中陽性を示した。

$10^{4}$ 個/羽投与群 (C 群) では, 投与第 2 日以降, 観察 期間中全例陽性を示し，ヶージ内大便は投与第 1 日から 陽性を示した。 また，羽毛は第 3 日から，消化管は第 2 日から殆んどすべてのものが陽性を示した。 また,ファ ブリシウス囊は第 $21 〜 49$ 日の間の 又検査を行なった がその間全例が陽性を示した。
$10^{7}$ 個/羽投与群（D群）では，投与第 1 日後上り全例 から投与菌が検出され，ケージ内大便も投与第 1 日から 全期間にわたり陽性を示した。

また, 蔵器別では, 盲腸, 直腸およびファブリシウス 䚉は全期間にわたりほとんどすべてのものが陽泩を示し たが, 羽毛拉よびその他の臓器は散発的に陽性を示し た.

3. 血中抗体 (H) は，A群と対照群はすべて陰性で あった，B群では第 21 日以降，C群では第 14 日以 降, D群では第 10 日以降からH抗体の産生が開始さ れ, その後, 徐々にH抗体価が上昇する傾向が認められ た.

\section{文献}

1）馬場純一：感染症学誌，49，170 (1975)。2) 藤田 雅: 第 79 回日本獣医学会 (1975). 3) 橋本秀 夫：メディヤサークル，13，251 (1968). 4) 貴田正 義：日本公衛誌，19，83(1972). 5) Ludkin, S.: Mthl. Bull. Min. Hlth. 14, 126 (1955)。 6) 松本治康: 太阪 府大紀要, 18, 73 (1966). 7) 岡崎秀信 : 日獣会誌, 24, 18 (1971). 8) SENCER, D. J., et al.: Salmonella suvveillance, 1973 1974, U. S. Department of Health, Education and Welfare, 121 123.9) 高塚 漣: 食品衛生研 究, 25, 841 (1975)。10） 田中 饒：日獣会誌， 27 , 475 (1974).

11) Thomas, E. M.: Mthl.Bull. Min. Hlth, 16, 29 (1957)。12）塚本定三：日獣会誌，26，66 (1973). 13）渡辺昭宣, ほか：日獣会誌, $28,296(1975), 14)$ 渡辺昭宣, ほか：日獣会誌，26，240(1973)。15) 渡 辺昭宣, 仿：日獣会誌，27,9 (1974)。16) 余田 岬: 第 75 回日本獣医学会 (1973).

\section{一日獣新刊図書案内一}

\section{愛犬家, 愛猫家の正しい飼育手引書として} 是非おすすめを

//I///犬とねこの正しい飼い方//I//

\section{一動物の保護および管理に関する法律のあらまし一}

監 修: 内閣総理大臣官房管理室

編集・発行：日本獣医師会

(編集担当者:一木彦三 猪野和郎 $⿴$ 日井和哉 柏倉 則文 久山登美雄 小暮規夫 山村穂積 和田 明)

\section{定 価 300 円（送料実費）}

〈動物保護・管理知識の㤵蒙, 普及用として最適〉 A 5 版 80 頁 カラー，色刷り，イラスト插入，美装 普及版

申込み先：日本獣医師会または所属地方獣医印会へ 